\title{
Isolation and Screening of Bacterial and Fungal Isolates for Plant Growth Promoting Properties from Tomato (Lycopersicon esculentum Mill.)
}

\author{
M. Rajendra Prasad*, B. Vidya Sagar, G. Uma Devi, S. Triveni, \\ S.R. Koteswar Rao and K. Damodara Chari
}

Department of Plant Pathology, College of Agriculture, PJTSAU Hyderabad, Telangana, India

*Corresponding author

\section{A B S T R A C T}

Keywords

Pythium

debaryanum,

Rhizoctonia

solani, Sclerotium

rolfsii,

Trichoderma

harzianum,

Trichoderma

viride,

Pseudomonas

fluorescence, Soil

borne pathogens.

Article Info

Accepted:

14 June 2017

Available Online:

10 August 2017

\begin{abstract}
In the present study About 24 isolates of fungal bio-control agent particularly Trichoderma spp and 12 bacterial isolates were isolated from the rhizosphere of tomato which was identified based on morphological and cultural characteristics. Among 24 isolates of Trichoderma spp ten and twelve bacterial isolates were identified with antagonistic ability and tested against the test soil borne pathogens $P$. debaryanum, $R$. solani and $S$. rolfsii. The Trichoderma harzianum-7 and Trichoderma harzianum-1 were found effective in inhibition of mycelium (80.03), (62.53 and 95.1) against $P$. debaryanum, $R$. solani and $S$. rolfsii respectively under in vitro conditions. The efficient isolates further screened for functional plant growth promoting properties. Among twelve bacterial isolates, Pseudomonas fluorescence-3 recorded highest solubilization zone followed by Pseudomonas fluorescence-2. All the bio-agents showed positive results to ammonia production except Trichoderma harzianum-6. Similarly all the bio-gents exhibited positive results for HCN production. Highest HCN production was observed with the Trichoderma viride-2, 9, 10 and Trichoderma harzianum-4, 7, 8, 13 and bacterial isolates of Bacillus subtilis-2, 4 and Pseudomonas fluorescence-10. IAA production was observed with Trichoderma but the highest IAA production was noticed with the bacterial isolates of Bacillus subtilis-5, Pseudomonas fluorescence-2 and 12. All the bacterial isolates showed siderophore production in the plate assay of which the bacterial isolates of Bacillus subtilis-4, Pseudomonas fluorescence-1 showed prominent orange colour zone. The Trichoderma viride 9 and Trichoderma harzianum-2 showed lower production of siderophores.
\end{abstract}

\section{Introduction}

Tomato (Lycopersicon esculentum Mill.) is an important vegetable crop which belongs to family Solanaceae. It is grown widely throughout the world under various agroclimatic conditions and attained the status of one of the world's most popular vegetables after potato, due to its high nutritive and medicinal value, in addition to processing and export potential. Tomato (Solanum lycopersicum L.) is a major contributor to the fruit vegetable diet of humans. It is cultivated in essentially all countries either in fields or in protected culture. Its many varieties are now widely grown, sometimes in greenhouses in cooler climates. Controlling such diseases mainly depend on fungicides treatments (Rauf, 2000). Tomato is prone to attack various fungal, bacterial, viral and nematode diseases at different stages of crop growth. 
The soil borne fungal pathogens viz., Pythium spp., Sclerotium rolfsii, Rhizoctonia solani and Fusarium oxysporum f. sp. lycopersici are known to cause damping-off, root rot, basal stem rot and wilt disease respectively in tomato. The tomato crop is also highly susceptible to damping of disease at seedling stage in nursery beds and the fungus, Pythium spp., (Edson) Fitz is common both in summer and winter grown tomato crops causing losses to the extent of 50 per cent (Bisht et al., 1997). Root rot caused by Rhizoctonia solani takes heavy toll in each season of its cultivation. It has been considered as the most devastating disease in Haryana destroyed the crop from early sowing until maturity, the disease may appear at any stage of growth in nursery beds as well as in field after transplanting. However, the damage is more marked at the early stage of the crop growth.

Sclerotium rolfsii, fungus is a soil borne facultative parasite having very wide host range which causes pre-emergence rot, damping off, collar rot, stem rot of tomato. This disease is also called by other names like southern blight, southern root rot, Sclerotium rot or white mold. The pathogen is polyphagous and non-target fungus. Biological control promises an environmental friendly disease management strategy for soil borne plant pathogens. Antagonistic fungi especially Trichoderma spp. and bacteria fluorescent Pseudomonads, Bacillus have been widely used against soil borne pathogens to reduce the population of Sclerotium spp., Rhizoctonia spp., Phytophthora spp. and Pythium spp. The biological control is the best alternative especially against soil borne pathogens. Biological control of pathogens, i.e., the total or partial destruction of pathogen populations by other organisms, occurs routinely in nature. Among the various antagonists used for the management of plant diseases, Trichoderma spp. plays a vital role. Recently, it was suggested that, Trichoderma affects induced systemic resistance mechanism in plants against pathogens (Haggag and Amin, 2001; Prasad et al., 2002; Hibar et al., 2007; Jayalakshmi et al., 2009). Among the various isolates of Trichoderma, T. Asperellum, T. harzianum, T. virens, T. viride, and $T$. hamatum are used against the management of various diseases of crop plants especially with soil borne pathogens. These filamentous fungi are very common in nature, with high population densities in soil and plant litters. Many studies have proved the potential of Trichoderma spp. as biological agents antagonistic to several plant pathogens (Tondje et al., 2007; Houssien, et al., 2010).

\section{Materials and Methods}

\section{Isolation of the antagonistic microflora} from the rhizosphere of tomato plants

Diseased and healthy plant samples with rhizosphere soil of tomato growing Mandals of Ranga Reddy districts on soil-borne fungal diseases during kharif 2013-14. Plants was collected in polythene bags from each survey plots and isolated immediately for antagonistic organisms by following serial dilution method.

Isolated fungal and bacterial antagonists from rhizosphere soil is transferred to culture tubes containing appropriate media for further examination. Identification was done up to genus level based on their cultural and morphological characterization (Barnett and Hunter, 1998).

\section{Identification of Trichoderma spp. and antagonistic bacteria}

Trichoderma spp. was identified based on keys as described by Rifai (1969), Rhizosphere bacteria were identified based on gram reaction of bacterial isolates was 
determined by following Gram staining and Biochemical Characterization by comparison with Bergey's Manual of Determinative Bacteriology. Trichoderma spp. and antagonistic bacteria were maintained by periodical transfer onto Potato Dextrose Agar and Nutrient Agar, respectively.

\section{Screening of pure isolates for plant growth promoting properties}

Pure isolates were isolated by streaking isolates on respective media plates and screened for following Plant growth promoting properties.

\section{Phosphate solubilization}

Phosphate solubilizing ability of the isolate was checked on Pikovskaya (PVK) medium (Pikovskaya, 1948). Incorporated with tricalcium phosphate (TCP) $\left[\begin{array}{ll}\mathrm{Ca}_{3} & \left(\mathrm{PO}_{4}\right)_{5}\end{array}\right]$. Phosphate solubilization index was evaluated according to the ratio of the total diameter (colony diameter + halo zone) and the colony diameter.

\section{Indole Acetic Acid Production}

Indole acetic acid production was tested according to Gorden and Weber (1951). Development of pink colour considered as positive for IAA production.

\section{Siderophore Production}

Siderophore production was estimated qualitatively on Chrome Azurol S (CAS) Agar medium (Schwyn and Neilands, 1987). Formation of yellow to orange coloured zone around the well indicates siderophore production.

\section{Hydrogen Cyanide Production (HCN)}

Pure isolate will be tested by inoculating on succinate agar using alkaline picric acid as a reagent (Castric and Castric, 1983), brown colour of the filter paper positive for $\mathrm{HCN}$ production.

\section{Ammonia production}

Ammonia production determined by the method (Dye 1962) after growing the different cultures in peptone water broth.

The tubes were incubated at $30^{\circ} \mathrm{C}$ for four days, after which $1 \mathrm{ml}$ of Nessler's reagent was added in each tube and observations were recorded in terms of a faint yellow colour, deep yellow to brownish colour. Three replicates per treatment were maintained.

\section{Results and Discussion}

About 24 isolates of fungal bio-control agent particularly Trichoderma spp and 12 bacterial isolates were isolated from the rhizosphere of tomato which was identified based on morphological and cultural characteristics. Trichoderma spp. and antagonistic bacteria were maintained by periodical transfer onto Potato Dextrose Agar and Nutrient Agar, respectively.

Among 24 isolates of Trichoderma spp ten and ten bacterial isolates were identified with antagonistic ability and tested against the test pathogens $P$. debaryanum, $R$. solani and $S$. rolfsii.

The Trichoderma harzianum-7 and Trichoderma harzianum-1 were found effective in inhibition of mycelium (80.03), (62.53 and 95.1) against $P$. debaryanum, $R$. solani and $S$. rolfsii respectively under in vitro conditions. All bacterial isolates morphologically and culturally characterized. These twelve isolates were gave gram negative and gram positive reaction. Further these isolates were characterized biochemical reactions using different sources. 
Plate.1 Phosphate solubilization on pikovskayas agar medium

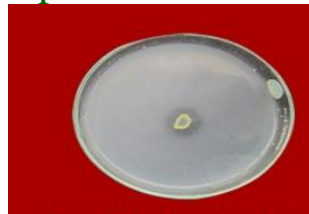

Bacterial isolate-9

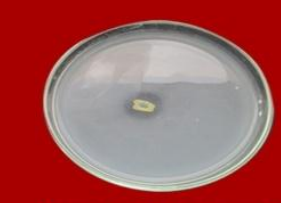

Bacterial isolate-4
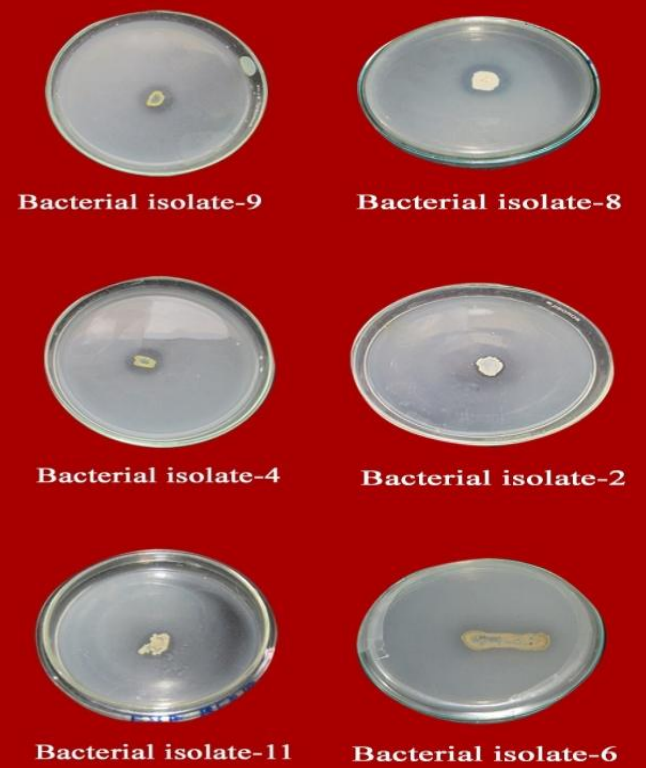

Bacterial isolate-8

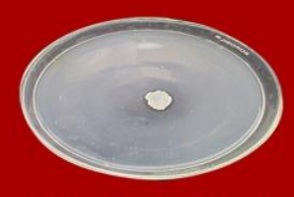

Bacterial isolate-2

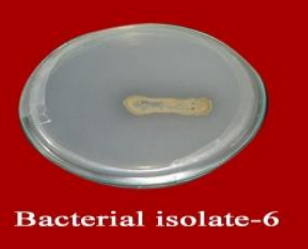

Plate.2 IAA production by Trichoderma and bacterial isolates
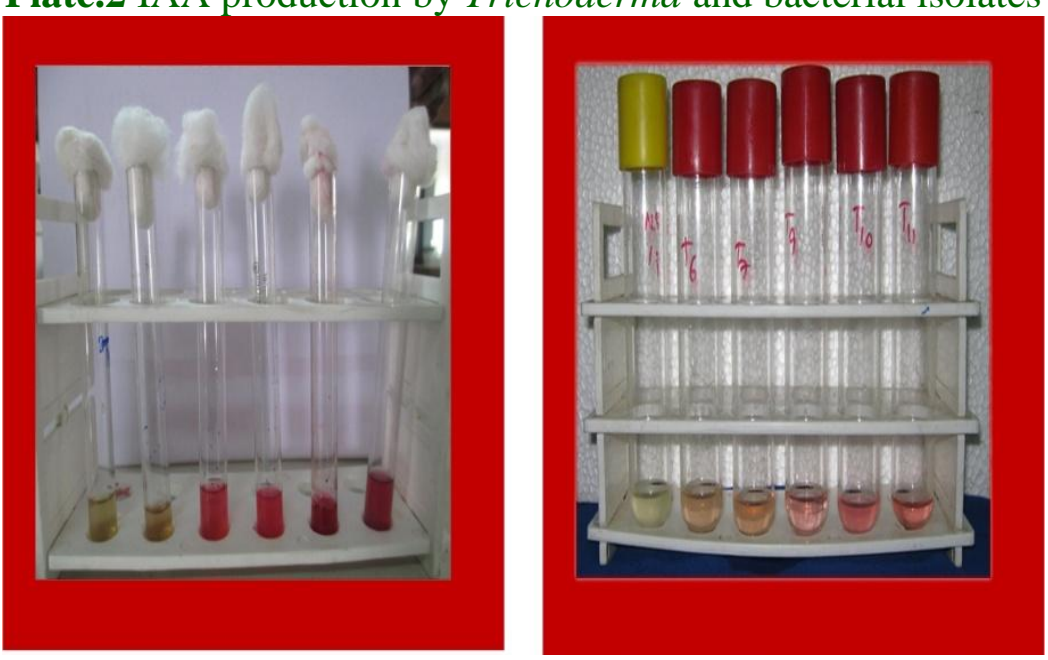

Plate.3 Siderophore production by Trichoderma and Bacterial isolates

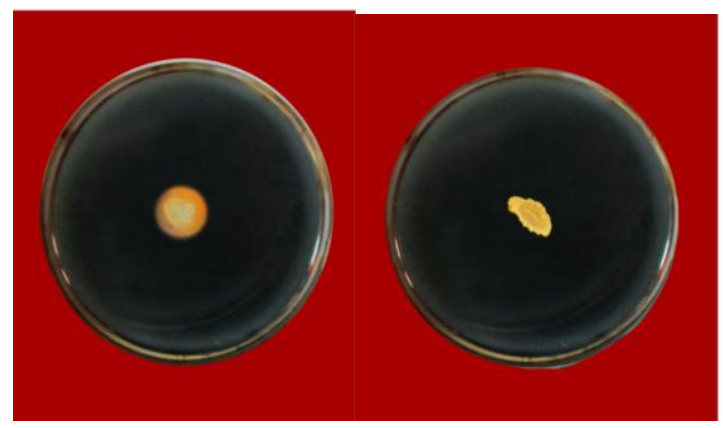

Plate.4 HCN production by Trichoderma and bacterial isolates

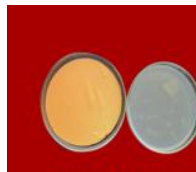

Bacterial isolate-2
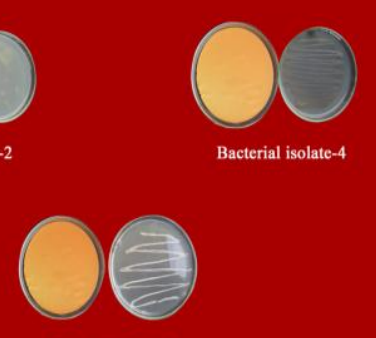

Bacterial isolate-8

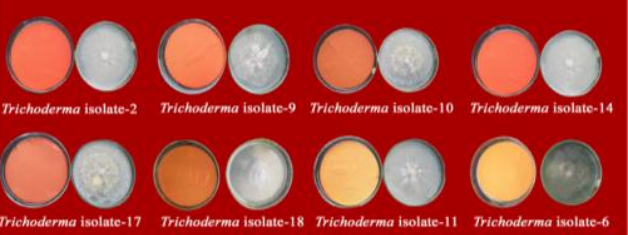

0000 
Table.1 Carbohydrate utilization of bio-chemical properties of rhizosphere bacteria isolated from tomato crop

\begin{tabular}{|c|c|c|c|c|c|c|c|c|c|c|c|c|c|}
\hline S.No & Test & Bac-1 & Bac-2 & Bac-3 & Bac-4 & Bac-5 & Bac-6 & P.f-1 & P.f-2 & P.f-3 & P.f-4 & P.f-5 & P.f-6 \\
\hline 1 & ONPG & - & - & - & - & - & - & - & - & - & - & - & - \\
\hline 2 & lysine & - & + & - & + & - & - & - & + & + & - & + & - \\
\hline 3 & ornithine & + & + & - & + & - & - & - & + & + & - & + & - \\
\hline 4 & Urease & - & - & - & - & - & - & - & - & - & - & - & + \\
\hline 5 & TDA & - & 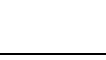 & & - & - & - & - & & & + & - & + \\
\hline 6 & Nitrate & - & + & + & + & + & + & - & + & + & - & - & - \\
\hline 7 & $\mathrm{H} 2 \mathrm{~S}$ & - & - & - & - & - & - & & - & - & & - & - \\
\hline 8 & Citrate utilization & - & - & + & + & - & + & + & - & - & + & - & + \\
\hline 9 & Vogesproskauer's & - & - & - & - & - & - & - & + & - & - & + & + \\
\hline 10 & Methyl red & - & - & + & - & - & - & - & - & - & - & - & + \\
\hline 11 & Indole & - & - & - & - & - & - & - & - & - & - & - & - \\
\hline 12 & Malonate & & - & - & - & + & + & - & - & - & - & -- & - \\
\hline 13 & Esculin hydrolysis & + & - & - & - & + & + & + & - & - & + & + & + \\
\hline 14 & Arabinose & - & - & - & - & - & - & - & - & - & + & + & + \\
\hline 15 & Xylose & 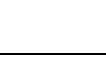 & - & - & - & - & - & 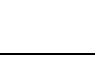 & - & - & + & + & + \\
\hline 16 & Adonitol & - & - & - & - & - & - & - & 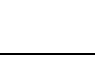 & - & + & - & - \\
\hline 17 & Rhamnose & + & - & & - & + & - & - & + & - & - & - & - \\
\hline 18 & Cellobiose & + & - & + & - & + & - & - & - & - & - & + & - \\
\hline 19 & Melibiose & + & - & - & - & - & - & - & + & + & + & + & + \\
\hline 20 & Saccharose & + & + & - & - & + & - & + & - & - & + & + & + \\
\hline 21 & Raffinose & + & & - & - & + & - & - & - & - & + & + & - \\
\hline 22 & Trehalose & + & + & - & - & + & - & - & + & + & + & + & + \\
\hline 23 & Glucose & + & + & - & - & + & - & - & + & + & + & + & + \\
\hline 24 & lactose & + & - & - & - & - & - & - & - & - & - & + & - \\
\hline
\end{tabular}

Bac - means Bacillus subtilis 1-6, P.f means- Pseudomonas fluorescence 1-6. 
Table. 2 Screening for plant growth promoting properties

\begin{tabular}{|c|c|c|c|c|c|c|c|}
\hline \multirow{3}{*}{$\begin{array}{l}\text { Isolates of } \\
\text { Bio-agents }\end{array}$} & \multicolumn{3}{|c|}{ Phosphate Solubilization } & \multirow{3}{*}{$\begin{array}{l}\text { Ammonia } \\
\text { production }\end{array}$} & \multirow{3}{*}{$\begin{array}{c}\text { IAA } \\
\text { production }\end{array}$} & \multirow{3}{*}{$\begin{array}{c}\text { Siderophere } \\
\text { production }\end{array}$} & \multirow{3}{*}{$\begin{array}{c}\mathrm{HCN} \\
\text { Production }\end{array}$} \\
\hline & \multicolumn{2}{|c|}{ Zone diameter (mm) } & \multirow{2}{*}{$\begin{array}{l}\text { Solubilization } \\
\text { efficiency }(\%)\end{array}$} & & & & \\
\hline & $\begin{array}{c}\text { Solubilization } \\
\text { zone }\end{array}$ & $\begin{array}{c}\text { culture } \\
\text { diameter }\end{array}$ & & & & & \\
\hline Trichoderma viride-2 & - & - & - & +++ & - & - & +++ \\
\hline Trichoderma viride- 6 & - & - & - & ++ & - & - & ++ \\
\hline Trichoderma viride-9 & 15.66 & 15 & 115.0 & +++ & + & + & +++ \\
\hline Trichoderma viride -10 & - & - & - & +++ & - & - & +++ \\
\hline Trichoderma viride -11 & - & - & - & + & - & - & ++ \\
\hline Trichoderma harzianum -1 & - & - & - & +++ & + & + & ++ \\
\hline Trichoderma harzianum -2 & - & - & - & ++ & - & + & +++ \\
\hline Trichoderma harzianum -5 & - & - & - & +++ & - & + & +++ \\
\hline Trichoderma harzianum -6 & - & - & - & - & - & - & +++ \\
\hline Trichoderma harzianum -11 & - & - & - & ++ & - & - & +++ \\
\hline Bacillus subtilis-1 & - & - & - & + & + & + & \\
\hline Bacillus subtilis -2 & 0.8 & 9 & 85 & ++ & ++ & ++ & +++ \\
\hline Bacillus subtilis-3 & - & - & - & ++ & + & + & - \\
\hline Bacillus subtilis-4 & 18 & 7 & 117.1 & +++ & +++ & +++ & +++ \\
\hline Bacillus subtilis - 5 & 16 & 15 & 105.0 & ++ & ++ & ++ & - \\
\hline Bacillus subtilis -6 & 20 & 15 & 135 & ++ & ++ & + & ++ \\
\hline Pseudomonas fluorescence-1 & 18 & 6 & 138.4 & +++ & +++ & +++ & - \\
\hline Pseudomonas fluorescence-2 & 2.6 & 5 & 140 & +++ & + & ++ & +++ \\
\hline Pseudomonas fluorescence-3 & 16 & 13 & 123.2 & ++ & ++ & ++ & ++ \\
\hline Pseudomonas fluorescence-4 & - & - & - & + & ++ & ++ & ++ \\
\hline Pseudomonas fluorescence-5 & 12 & 8 & 125 & ++ & + & + & ++ \\
\hline Pseudomonas fluorescence-6 & 22 & 11 & 130 & ++ & +++ & ++ & ++ \\
\hline
\end{tabular}




\section{Biochemical characterization of bacterial isolates}

Carbohydrate utilization patterns of the bacterial isolates were studied using biochemical kits supplied by Himedia and the reactions are presented in table 1 and Plate-1. The bacterial isolates tested could not utilize O-Nitrophenyl $\beta$-D galacto pyranoside (ONPG). The Bacillus subtilis isolates 2, 4 and Pseudomonas fluorescens-2, 3 and 5 could utilize decarboxylate lysine and ornithine and the Pseudomonas fluorescens-6 utilized urea as a nitrogen source. Out of twelve isolates, seven isolates (Bacillus subtilis isolates -2, 3, 4, 5, 6, Pseudomonas fluorescens 2 and 3) preferred nitrite as the nitrogen source whereas isolate Pseudomonas fluorescens-4 and Pseudomonas fluorescence isolate- 6 utilized phenylalanine.

Among the carbon sources tested, most of the bacterial isolates (Bacillus subtilis isolates-1, 2, 5 and Pseudomonas fluorescence isolate-2, $3,4,5,6)$ utilized glucose and trehalose as preferred carbon sources followed by saccharose (Bacillus subtilis isolates 1, 2, 5 and Pseudomonas fluorescence 1, 4, 5, 6) and melibiose (Bacillus subtilis isolate-1, Pseudomonas fluorescence 1, 2, 4, 5, 6). Raffinose as carbon source was utilized by the bacterial isolates Bacillus subtilis-1, 5 and Pseudomonas fluorescence-4 and 5 and Cellobiose by Bacillus subtilis-1, 3, 4 and Pseudomonas fluorescence-5. Arabinose and xylose was utilized by the bacterial isolates of Pseudomonas fluorescence-4, 5 and 6. Lactose and adonitol were found be the least preferred carbon source by the bacterial isolates. The ability of the bacteria to utilize different substrates containing carbon, hydrogen and oxygen varies with the battery of enzymes present in the bacteria (Cowan, 1974). For example, none of the isolates tested were found to possess $\beta$-galactosidase activity as they couldn't utilize ONPG.

\section{Screening for plant growth promoting} properties

In the present study, all the fungal and bacterial isolates were used to study the phosphate solubilization. Among twelve bacterial isolates, eleven bacterial isolates showed solubilization zone except Pseudomonas fluorescence-4. The Pseudomonas fluorescence-2 recorded highest solubilization zone followed by Pseudomonas fluorescence-1. All Trichoderma isolates did not show any phosphate solubilization zone (Table 2 and Plate 1).

All the bio-agents showed positive results to ammonia production except Trichoderma harzianum-6. The dark colour was recovered in Trichoderma viride-2, 9, 10, Trichoderma harzianum-2 and 5 and Bacillus subtilis isolates-4, Pseudomonas fluorescence-1 except bacterial isolate Bacillus subtilis-5. Similarly all the bio-gents exhibited positive results for $\mathrm{HCN}$ production. Highest $\mathrm{HCN}$ production was observed with the Trichoderma viride isolates-2, 9, 10, Trichoderma harzianum-2, 5, 6, 11 and bacterial isolates of Bacillus subtilis-2, Pseudomonas fluorescence-2 and 3 (Plate 4). IAA production was observed with Trichoderma but the highest IAA production was noticed with the bacterial isolates Bacillus subtilis-5, Pseudomonas fluorescence-2 and 6 (Plate 2). All the bacterial isolates showed siderophore production in the plate assay of which the bacterial isolates of Bacillus subtilis- 4, Pseudomonas fluorescence-1 showed prominent orange colour zone. The Trichoderma viride-9 and harzianum-2 showed lower production of siderophores (Plate 3).

The present study was undertaken in order to isolate and identify tomato-associated Trichoderma and rhizobacteria from various 
tomato-producing sites and growing systems and to perform morphological, biochemical characterization. The current investigation provided strong evidence that tomato rhizosphere was populated by a numerous and a diverse array of rhizobacteria exhibiting a great morphological and biochemical diversity. Screening of their ability to synthesize plant growth-promoting and antifungal compounds revealed that the majority of isolates were able to produce siderophore, to solubilize phosphate and to synthesize IAA and that interestingly, some isolates cumulated the three plant growth promoting traits.. Thus, this study clearly demonstrated that tomato rhizospheric soils harbor a diversity of beneficial bacteria which may be promising biocontrol agents due to their interesting metabolic activity and their interesting antifungal potential displayed toward both target fungi. Moreover, their ability to produce plant growth-promoting compounds indicated that they may exhibit a bio-fertilizing action.

\section{References}

Abd-El-Kareem, F. 2007. Induced Resistance in Bean Plants Against Root Rot and Alternaria Leaf Spot Diseases Using Biotic and Abiotic Inducers under Field Conditions. Research Journal of Agriculture and Biological Sciences. 3(6): 767-774.

Barnett, H.L and Hunter, B.B. 1998. Illustrated genera of imperfect fungi. $3^{\text {rd }}$ Edition. Burgess Publishing Co. Pp. 273.

Bisht, G.S., Chandrajoshi, Bisht, D and Kuble. 1997. Distribution and pathogenicity of Pythium spp. from tomato. Indian Phytopathology. 50 (1): 83-97.

Castric, K.F and Castric, P.A. 1983. Method for rapid detection of cyanogenic bacteria. Applied and Environmental
Microbiology. 45: 700-702.

Cowan ST. 1974. Cowan and Steel's Manual for the Identification of Medical Bacteria. 2nd edn. Cambridge University Press, Ames.

Gordon, S. A. and Webrm, R.P.1951. Colorimetric estimation of indole acetic acid. Plant Physiology. 26: 192-195.

Haggag, W. and A.W. Amin. 2001. Efficiency of Trichoderma species on control of Fusarium- rot, root knod and Reniform nematodes disease complex on sunflower. Pakistan Journal of Biology and Science. 4(3): 314-318.

Hibar, K., M. Daami-Remadi and M. ElMahjoub. 2007. Induction of resistance in tomato plants against Fusarium oysporum f.sp, radicislycopersici by Trichoderma spp. Tunisian J. Plant protection. 2(1): 47-58.

Houssien, AA. Ahmed S.M. and Ismail. A.A. 2010. Activation of Tomato Plant Defense Response against Fusarium Wilt Disease Using Trichoderma harzianum and Salicylic Acid under Greenhouse Conditions. Research Journal of Agriculture and Biological Sciences. 6(3): 328-338.

Jayalakshmi, S.K., S. Raju, S. Usha-Rani, V.I. Benagi and K. Sreeramulu. 2009. Trichoderma harzianum L1 as a potential source for lytic enzymes and elicitor of defense responses in chickpea (Cicer arietinum L.) against wilt disease caused by Fusarium oxysporum f. sp. ciceri. Australian Journal of Crop Science. 3(1): 44-52.

Pikovskaya, R.I. 1948. Mobilization of phosphorus in soil connection with the vital activity of some microbial species. Microbiologiya. 17: 362-370.

Prasad, R.D., S.V. Rangeshwaran, S.V. Hegde and C.P. Anuroop. 2002. Effect of soil and seed application of Trichoderma harzianum on pigeonpea wilt caused by Fusarium udum under 
field condition. Crop Protection. 21: 293-297.

Rauf, B.A. 2000. Seed-borne disease problems of legume crops in Pakistan. Pak. J. Sci. and Industrial Res. 43: 249254.

Rifai, M.A. 1969. A revision of the genus Trichoderma. Mycological Papers. Pp. 116: 1-56.

Rojo, F., G., Reynoso, M. Sofia, M. F. and Torres, A. M. 2007. Biological control by Trichoderma species of Fusarium solani causing peanut brown root rot under field conditions. Crop protection. 26:549-555.
Tondje PR., Roberts DP., Bon MC, Widner T, Samuels GL, Ismaiel, A., Begoude, A.D., Tchana, T., Nyemb-Tshomb, E., Ndounbe-Nkeng, M., Bateman, R., Fontem, D. and Hebbar, K.P. (2007). Isolation and identification of mycoparasitic isolates of Trichoderma asperellum with potential for suppression of black pod disease of cacao in Cameroon. Biological Control. 43: 202-212.

Schwyn, B and Neilands, J.B. 1987. Universal chemical assay for the detection and determination of siderophores. Annals of Biochemistry. 160:47-56.

\section{How to cite this article:}

Rajendra Prasad, M., B. Vidya Sagar, G. Uma Devi, S. Triveni, S.R. Koteswar Rao and Damodara Chari, K. 2017. Isolation and Screening of Bacterial and Fungal Isolates for Plant Growth Promoting Properties from Tomato (Lycopersicon esculentum Mill.). Int.J.Curr.Microbiol.App.Sci. 6(8): 753-761. doi: https://doi.org/10.20546/ijcmas.2017.608.096 